\title{
THE ENIGMA OF THE FOURTH GOSPEL: ANOTHER LOOK ${ }^{1}$
}

\author{
David Wenham
}

\section{Summary}

The Fourth Gospel is often said to have derived from a situation at the end of the first century when the Christian church had finally separated from the synagogue. Such a view is thought to explain the gospel's polemic against 'the Jews', its dualistic outlook and other-worldly Christology, and its sectarian emphasis on Christians loving 'one another'. However, these Johannine emphases are shown in this article to have significant parallels in Christian traditions that can be traced back to the time of Paul and perhaps earlier. The probability is that the author of the Fourth Gospel has highlighted certain strands in early Jesus tradition more than the Synoptic Gospels because of controversies about the person of Jesus inside and outside the Christian church.

\section{A Scholarly Consensus regarding the Fourth Gospel}

The differences between the Synoptic Gospels and the Fourth Gospel are substantial, as is well known. The usual explanation for these differences, which commands the assent of most scholars, is that the Fourth Gospel's account of Jesus is more theologically coloured and less historically traditional than that of the Synoptic Gospels. Modern scholars speak of the Fourth Gospel being preaching about Jesus, ${ }^{2}$ as 'poetic' or 'charismatic

${ }^{1}$ This article has a dual-dedication. First, to the memory of my father, John Wenham, who died on 13 February 1996, and who had hoped to follow his published works on the Synoptic Gospels with a study of the Fourth Gospel. Second, to John Ashton on the occasion of his 65th birthday.

${ }^{2}$ E.g. B. Lindars, John (Sheffield: JSOT, 1990) 36-37 on the discourses in particular; also his commentary, The Gospel of John (Grand Rapids: Eerdmans; London: Marshall, 1972) 51-52. 
history', ${ }^{3}$ of a 'two-level drama'. 4 The Fourth Gospel, on this view, is a heavily reinterpreted account of Jesus, which reflects the situation and theology of its author(s) at least as much as the situation and theology of Jesus. The author justifies his stylised account implicitly by his frequent references to the Spirit's inspiration of Jesus' disciples.

There was a time when scholars saw the Fourth Gospel as a hellenistic reinterpretation of the Jewish Jesus-tradition. Although that view does probably have an important grain of truth in it,, it has now largely been discarded, as scholars have come to appreciate the very Jewish and even Palestinian character of the Fourth Gospel. The discovery of the Dead Sea Scrolls not only helped persuade scholars that Palestinian Judaism was much more hellenized than had been thought, but also threw up some particularly interesting parallels with the Fourth Gospel.

In place of the old consensus that saw the Fourth Gospel as a hellenistic reinterpretation of traditions about Jesus, the new consensus sees the Fourth Gospel as arising out of a crisis that took place towards the end of the first century A.D., after the Christian community out of which the Fourth Gospel came had split from Judaism. The Council of Jewish rabbis which took place in Jamnia in Galilee about 85 A.D. is thought to have been responsible for the split, because they introduced into the synagogue liturgy (the Eighteen Benedictions) a public cursing of the 'heretics' (the minim) and perhaps of the 'Nazarenes'. This curse is thought to have been directed against the Christians, and its effect was finally to drive out the Christians, who until now had remained part of the Jewish community, from the synagogue and from Judaism.

${ }^{3}$ M. Stibbe, John (Sheffield: JSOT, 1993) 18-19. J. Ashton in his magnum opus, Understanding the Fourth Gospel (Oxford: OUP, 1994) 432, speaks of the Fourth Gospel as more a creed than biography, let alone history.

4J.L. Martyn, History and Theology in the Fourth Gospel (Nashville: Abingdon, 19792) 24-36 and passim.

${ }^{5}$ For example, it remains probable that the logos theology in Jn. 1, though very Hebraic, is intended to make sense to those familiar with Greek ideas of the logos. 
This painful post-Jamnia situation is thought to be reflected in various of the distinctives of the Fourth Gospel. First, there is the animosity of the Fourth Gospel towards 'the Jews', and in particular the references to followers of Jesus being put 'out of the synagogue' $(9: 22 ; 16: 2)$. Second, there is the dualistic flavour of the Fourth Gospel: its sharp differentiation between Jesus' followers and 'the world', between 'light' and 'darkness', between the disciples as people who have revelation and who 'know' and others (especially the Jews) who are blind and who face judgement. All these are thought to point to what sociologists describe as a 'sectarian' situation, in this case produced by the ruptured relationship between the synagogue and the Johannine community. Third, and following on from this, the Christology of the Fourth Gospel has been explained in terms of this situation, with the portrait of Jesus as a heavenly other-worldly figure explaining the unhappy failure of the Jews to understand and believe. Fourth, the distinctive ethical imperative in the Fourth Gospel 'to love one another' makes sense in such a situation since sectarian groups often have strong communal and inward-looking concerns. ${ }^{6}$

This view is attractive in explaining many of the most striking features of the Fourth Gospel. However, it is the thesis of this article that, like many scholarly consensuses, it is less persuasive than it might at first appear, and that we should be looking in some rather different directions for an explanation of the distinctiveness of the Fourth Gospel.

\section{Doubts about the Consensus}

\section{a. The Jamnia hypothesis}

The first problem with the modern consensus is its dependence on a highly uncertain view about what happened in Jamnia. Various scholars have questioned whether Jamnia did mark a

\footnotetext{
${ }^{6}$ The most influential proponent of the Jamnia hypothesis has been Martyn (History and Theology). On the Fourth Gospel as sectarian, see especially W.A. Meeks, 'The Man from Heaven in Johannine Sectarianism', JBL 91 (1972) 44-72, reprinted in J. Ashton (ed.), The Interpretation of John (London: SPCK; Philadelphia: Fortress, 1986) 141-43.
} 
decisive break between church and synagogue: there are doubts about what exactly happened at the Council of Jamnia, about what was or was not put into the liturgy, about whether it was intended to exclude Christians from the synagogue, and about whether it had that effect.?

\section{b. Historical traditions in the Fourth Gospel}

Although the scholarly consensus has tended to see the Fourth Gospel as theological rather than historical (to a degree that exceeds the Synoptic Gospels), there has also been widespread recognition in recent years that the evangelist had access to his own traditions of Jesus, whether or not he knew the Synoptic Gospels. In some cases at least, those traditions have a highly Palestinian flavour, and may be as historical as well-attested synoptic traditions. 8

\section{III. 'Late' Features of the Fourth Gospel}

As we have seen, the Jamnian hypothesis offers a neat explanation for some of the distinctives of the Fourth Gospel. However, in no case does the evidence demand the Jamnian conclusion, and in each case there is strong evidence indicating that the relevant features of the Fourth Gospel at least have

${ }^{7}$ Cf. J.P. Lewis, who reviews the Jamnia hypothesis and suggests that it should 'be relegated to the limbo of unestablished hypotheses' (Anchor Bible III, 634-37 (ed. D.N. Freedman et. al.; Doubleday: New York, 1992). The eschatological traditions of the gospels, especially of Mt. 24/Mk. 13/Lk. 21, may indicate that the events of 66-70 A.D. themselves (rather than the Jamnian Council) were seen by Christians as marking the decisive break with Judaism.

${ }^{8}$ The description of Jesus baptising in Judea, before his Galilean ministry, alongside John the Baptist in 3:22-26 and 4:1-3 is a case in point. See R.E. Brown, The Gospel according to John i-xii (London: Chapman, 1971) 155; Lindars, Gospel, 164. The scholar who in recent years had most strikingly argued for historical traditions in the Fourth Gospel is J.A.T. Robinson. His book The Priority of John (London: SCM, 1985) accumulates important evidence which has not always been sufficiently recognised by other scholars. Robinson's weakness, arguably, is in his failure to account sufficiently for the Fourth Gospel's wide divergence from the Synoptic Gospels. 
their roots very early in the history of Christianity and long before Jamnia.

\section{a. The Johannine thunderbolt in $\mathbf{Q}$}

In support of this claim, we note first the famously Johannine sayings found in Matthew 11:25-27 and Luke 10:21-22:

I thank you, father, Lord of heaven and earth, that you hid these things from the wise and understanding, and revealed them to babes. Yes, father, because such was your good pleasure. All things have been delivered to me by my father, and no one knows the son except the father, nor does anyone know the father except the son and anyone to whom the son wishes to reveal him.

' $Q$ ' sayings such as this are usually seen as relatively primitive tradition, going back to the $60 \mathrm{~s}, 50$ s or earlier, ${ }^{9}$ but this one is outstandingly Johannine, with its father/son language, its emphasis on revelation and the knowledge of father and son, and its epistemological dualism (i.e. the truth being known to the disciples but concealed from others). What this shows is that these Johannine themes need not necessarily have come out of a Jamnian context; the most one could say is that the Fourth Evangelist has emphasised these themes because of his Jamnian context; what is an isolated saying in the Synoptic Gospel has become a very important stratum in the Fourth Gospel. And yet it is hard to believe that, in the traditions of the ' $Q$ ' community (i.e. the community that preserved the saying), there was just one 'thunderbolt' saying of this sort. It seems likely that the saying reflects a perspective on Jesus that was important in this early Christian community.

${ }^{9}$ Some scholars see these sayings as representing a late stratum in $\mathrm{Q}$ (e.g. J.S. Kloppenborg, The Formation of $Q$ [Philadelphia: Fortress, 1987] 198203). But even if they are right, the sayings still presumably antedate Matthew, Luke and John. Other scholars recently have questioned the $Q$ hypothesis and have argued for Lukan use of Matthew. I am personally unpersuaded of the existence of $Q$, but I am convinced that in ' $Q$ ' material Luke sometimes has the earlier form of wording, and that the proponents of $Q$ are right to see ' $Q$ ' tradition as antedating Matthew and Luke. If, however, Luke did get the material in question from Matthew, still the Fourth Gospel is seen to be less distinctive than has often been supposed. 


\section{b. The Markan saying about the purpose of parables.}

Another saying which reflects precisely this perspective is the saying about the purpose of parables found in Mark 4:11-12, Matthew 13:11, and Luke 8:10. The Markan version is: 'To you the mystery has been given of the kingdom of heaven; but to those outside everything happens in parables.' Matthew and Luke differ slightly from Mark, but have a striking range of small agreements with each other in wording and word-order: 'To you has been given to know the mysteries of the kingdom.' The agreement of Matthew and Luke here probably points to their having a non-Markan tradition; 10 so the saying is doubly attested and quite likely primitive. Significantly, the same epistemological dualism and emphasis on revelation appears in this tradition as was found in the $Q$ saying above (even the same Greek verb of knowing, if we follow Matthew and Luke). The saying in this case is not so richly Johannine, but it confirms that features of the Fourth Gospel that have been seen to be Jamnian actually go far back in the early history of the Jesus-tradition.

Two further observations with regard to this text are relevant. First, the synoptic saying leads into an allusion to Isaiah 6:10, a text echoed twice in the Fourth Gospel (9:39; 12:40). Second, the synoptic saying about mysteries being revealed and about 'parables' is reminiscent of thinking found in the Dead Sea Scrolls, notably in 4QpHab VII. Interestingly some recent scholars have postulated that the author of the Fourth Gospel was originally an Essene. ${ }^{11}$ On this hypothesis, a strand of early Christianity may have been influenced by and reflect Essene features.12 Whether or not this is the case, it may be good to be reminded that the Dead Sea Scrolls represent a dualistic 'sectarian' way of thinking that is in some ways paralleled in the Fourth Gospel but that has nothing to do with

${ }^{10}$ See J. Nolland, Luke 1-9:20 (Waco: Word, 1989) 377; also my 'The Synoptic Problem Revisited: Some New Suggestions about the Composition of Mark 4:1-34', TynB 23 (1972) 3-38, especially 27.

${ }^{11}$ E.g. Ashton, Understanding, 232-37.

${ }^{12}$ See further, D. Sefa-Dapaah, An Investigation into the Relationship between John the Baptist and Jesus of Nazareth: A Socio-Historical Study (Ph.D. thesis for Coventry University in collaboration with Wycliffe Hall, 1995). 
Jamnia. If, as various scholars have argued, the early Christians were in some way associated with the Essenes, then the 'sectarianism' of the Fourth Gospel may well have derived from that association.

\section{c. Baptism and transfiguration}

Scholars have discussed at length the absence from the Fourth Gospel of any account of Jesus' baptism or transfiguration. What makes the absences the more remarkable is the 'Johannine' flavour of the narratives, with Jesus being identified as the divine 'son', as the one specially 'loved' by the father, and (in the baptism narrative) as the bearer of the father's Spirit. ${ }^{13}$ In both stories, the boundary between the heavenly and the earthly realms is broken through.

For our purposes, it is not necessary to discuss the reasons for the Fourth Gospel's failure to reproduce the narratives. What is significant is the evidence provided by these synoptic traditions of the existence and importance of what are often seen as Johannine Christological themes in pre-Johannine Synoptic tradition. The baptism of Jesus by John is widely regarded as a historical event by modern scholars, and it seems to have been recognised in all ancient Christian tradition as the starting-point of Jesus' ministry. It is not possible to prove at what point it came to be associated with ideas of divine sonship and Spirit-anointing, but it is arguable that these baptismal ideas, like the ' $Q$ ' thunderbolt, are early. ${ }^{14}$ Evidence from Paul also has some importance here.

\section{d. The evidence from Paul}

Even more striking evidence that the distinctives of the Fourth Gospel need not point to a post-Jamnian situation is provided by Paul.

\footnotetext{
${ }^{13} \mathrm{Also}$ in the baptism narrative is the idea of Jesus as the one who conveys the Spirit to others (baptising them with the Spirit).

${ }^{14}$ The fact that Jesus' baptism by John was remembered at all and was given such prominence in the early church could suggest that it was seen as out of the ordinary and as charged with special significance from the beginning. On the great importance of the transfiguration story in the early church, see D. Wenham and A.D.A. Moses, "There are Some Standing Here"...', NovT 36 (1994) 146-63.
} 
(i) 1 Thessalonians 2:13-16. 1 Thessalonians is agreed to be Paul's earliest or second earliest extant letter, to be dated about 50 A.D., and the way that Paul speaks there of 'the Jews, who killed the Lord Jesus and the prophets and also drove us out' is rightly noted by John Robinson and others as a striking parallel to the Johannine way of speaking of 'the Jews' and of the Jews putting Christians 'out of the synagogue'.15 There is thus no need to look to the Jamnian situation to make sense of this Johannine feature.

Admittedly, scholars have tried to distinguish between the sort of expulsion described in 1 Thessalonians and that described in the Fourth Gospel, but it is doubtful if the distinction can be seriously maintained. It may be that there is no definite evidence of an agreed policy by 'the Jews' to expel Christians from the synagogue before Jamnia, but there is plenty of evidence of some very vicious attacks on the early Christian movement (Paul himself being involved before his conversion), 16 and it is highly likely that the campaign against the Christians included the relatively moderate measure of excommunicating Christians from the synagogue. 17 To say this is not necessarily to deny that the wording of a passage like John 9 could reflect late first-century A.D. tensions between Jews and Christians, but there is no reason why the Johannine references to 'the Jews' and to expulsions from the synagogue should not go back substantially to a far earlier date.

(ii) 1 Corinthians 1-4. I Corinthians may be dated to about 55 A.D., and what is most striking here is the emphasis on Christian revelation and knowledge. The Corinthian Christians were a strongly charismatic community, who were excited by their experiences of the Spirit and by what had been and was being revealed to them by the Spirit: they had 'words of wisdom' and 'words of knowledge'; they were keen on eloquence and wisdom (perhaps influenced by Apollos the

${ }^{15}$ So Priority of John, 81-86.

${ }^{16} \mathrm{On}$ the possibility of ongoing persecution of Christians after the crucifixion during the time of Pilate, see R. Riesner, Die Frühzeit des Apostles Paulus (Tübingen: Mohr, 1994) 55-56.

${ }^{17}$ Our basic argument stands, therefore, even if some dispute the authenticity of 1 Thess. 2:14-16. 
Alexandrian); and they were proud of their 'knowledge', which, for example, enabled them to eat food offered to idols with a good conscience. Paul has an ambivalent attitude to the Corinthians on these matters: he rejects their arrogance, their boasting about human beings, and their failure to think of the weaker brother or sister. But he too can speak of the Christian 'knowing' God, and he agrees with them that Christians have a 'secret wisdom...that has been hidden' but which 'God has revealed to us' now by his Spirit-a wisdom that 'the spirit of the world' cannot understand $(2: 7,10,12)$.

Accordingly, already in Corinth in the 50 s we find various emphases and ideas that are also important in the Fourth Gospel, including the emphasis on revelation, on knowing God, and also on the Spirit. We do not find much emphasis on 'wisdom' in the Fourth Gospel, but the concept of 'the Word' in the Johannine prologue is regularly linked with the Jewish wisdom concept; we do not find the Johannine notion of Jesus as 'the word' in 1 Corinthians, and yet 'words' of revelation are important. 18 It would be unwise to make too much of such parallels, but it is possible that the charismatic Corinthians are much more Johannine than we might at first suppose, with their highly realised eschatology and their emphasis on the great works of the Spirit that featured in their community. ${ }^{19}$ The Johannine view of the Christian community

18It is not at all impossible that Apollos would have been familiar with the Philonic doctrine of 'the word'. For a possible link between the Johannine 'word' and Pauline tradition, see arguably Col. 1:25, where 'the word of God' is in apposition to 'the mystery hidden'; so J. Ashton, Studying John (Oxford: OUP, 1994) 22 (though he also notes differences between the Colossian hymn and the Johannine prologue).

${ }^{19}$ Interestingly E. Käsemann, The Testament of Jesus (London: SCM, 1968) 24 , suggests that the Fourth Gospel may have originated in circles in the 'enthusiastic' tradition opposed in 1 Cor. 15 and 2 Tim. 2:18, and that the fourth evangelist may be endeavouring to 'combat a development in the church which did not take Christology sufficiently into account...the controversy dealt with the slogan solus Christus'. Ashton, Understanding, 92-93, comments on the 'slender evidence' for Käsemann's view, but perhaps this article contributes some further evidence. I would not call Corinthian enthusiasm or Johannine Christianity 'gnostic', though they may very well represent tendencies that develop into gnosticism. See further below; also my Paul, Follower of Jesus or Founder of Christianity 
as having special revelation that sets it apart from 'the world' need not, therefore, point to a late first-century A.D. context, but would be just as much at home in a mid-first century Corinthian context.

But we can take the argument a step forward by asking: From where did the Corinthians get their emphasis on knowledge and revelation? Apollos may have been influential, but Paul owns that emphasis for himself, even though he objects to some ways it has been used by the Corinthians. And it seems entirely probable that it was Paul himself who taught the Corinthians about the Spirit's power and revelation. If he did, where did he get the ideas from? There is good reason to think that in this, as in so many other matters, Paul was influenced by Jesus-traditions with which he was familiar.

In support of this proposal, the evidence of 1 Corinthians 13:2 is relevant. Paul's words here about 'having all faith so as to move mountains' have often been linked to the Jesus-traditions of Mark 11:23 and parallels, and his words in the same verse about 'knowing all mysteries and all knowledge' are plausibly linked to the dominical saying about parables (Mk. 4:11-12 and parallels). ${ }^{20}$ In 1 Corinthians 13, Paul's point is that, without love, all the powers that Jesus promised his followers are worthless.

Other relevant evidence is in 1 Corinthians 1-4. Various scholars have suggested that the Corinthians were influenced by the saying of Matthew 11:27 and Luke 10:21-22. Echoes of those synoptic passages might be heard in Paul's language of

(Grand Rapids \& Cambridge: Eerdmans, 1995) 286. R. Bultmann, The Gospel of John (Oxford: Blackwells, 1971) 9-10, finds the fourth evangelist and Paul influenced by gnosticism. He denies that the former has been influenced by the latter, arguing that the differences are too great, noting, for example, the unimportance of 'righteousness' in the Fourth Gospel, and differences in eschatology. Even at these points, however, the Johannine and Pauline traditions do not seem so different if 1 John is brought into the discussion, since we find there a greater interest in 'Pauline' themes such as atonement, righteousness and the parousia (1:7$2: 2 ; 2: 18)$. In the Fourth Gospel 'righteousness' is only found in 16:8 and 16:10: the trio there, 'sin', 'righteousness' and 'judgement' is somewhat reminiscent of Paul. I am grateful to John Muddiman for this observation. 20See further my Paul, 81-84. 
'hiding', 'revealing', 'wise', 'foolish', and 'babes', and it may well be that the Corinthians were claiming to be in the privileged position described by the ' $Q$ ' saying. There are other possible echoes of the ' $Q$ ' saying in 1 Corinthians, including 2:11: 'No one knows the things of God except...'. The echoes are not such as to prove dependence on the dominical tradition, but, given the importance of such tradition in Paul's teaching to the Corinthians (e.g. 7:3-4;11:23-25; 15:1-7), it is at least a plausible hypothesis. ${ }^{21}$

We conclude (a) that the Johannine emphasis on revelation and knowledge had important precedents in Christian traditions dating back to the 50s, and (b) that these traditions were already regarded as dominical. We may surmise that the fourth evangelist, Paul and the Corinthians are all drawing on a common strand of Jesus-tradition. 22

(iii) Christology. If the polemic against the Jews in the Fourth Gospel and its emphasis on revelation have striking parallels in early Christian tradition, what of its distinctive Christology, including its emphasis on Jesus as the pre-existent son of the father who came down from heaven? Is not this rightly recognised as the end-point in the development of Christological thinking in the New Testament church, and as belonging in something like the Jamnian context?

21See my Paul, 129-36, referring to the work of J.M. Robinson, H. Koester, B. Fjärstedt, and P. Richardson.

22If this is the case, then it is interesting to speculate about what that Jesustradition might have contained. Did it perhaps simply contain the ' $Q$ ' saying of Mt. 11:27/Lk. 10:21, 22 and the Markan logion about parables (Mk. 4:11-12)? Or did it more probably contain other traditions, which are in common in the Fourth Gospel and 1 Corinthians? Did it, for example, contain substantial teaching about the charismatic Spirit and his work? This is inevitably speculative, but we suggested before that it is not likely that the 'Johannine thunderbolt' was a totally isolated saying and that there probably was a wider body of material of which it was a part.

Teaching about baptism, associating it with the gift of the Spirit, may also have featured significantly ( $c f .1$ Cor. 12:13; Jn. 3:5). The Fourth Gospel ascribes to Jesus teaching on the Paraclete-Spirit, being the Spirit of Jesus and the revealer of truth, and of the disciples doing great works (14:12). The ideas are not dissimilar to Pauline ideas: though Paul does not speak of the 'Paraclete', the noun paraklesis and the verb parakaleo are important to him, e.g. in 2 Cor. 1. 
Paul's evidence tells against this conclusion. The Christhymn of Philippians 2:5-11, for instance, speaks of a preexistent Christ, who humbled himself and who then was 'super-exalted' by God.23 Jesus is not described as one who 'descended' and 'ascended' as in the Fourth Gospel, but the thought is similar and the language is also closely related, with Paul's 'super-exalt' being the same root as characteristic references in the Fourth Gospel to Jesus being 'lifted up'.24 Of course, the Pauline passage is very widely seen as a hymn that antedates the letter to the Philippians, and, if that opinion is correct, then we are taken back even earlier into the history of Christian thought.

Another hymn in the Pauline letters is Colossians 1:1520, and the similarities here to the Fourth Gospel and especially to its prologue are manifest: Jesus is the pre-existent son, involved in creation (like the wisdom of God in Jewish tradition) and then indwelt by all the fullness of God. If those scholars are right who regard Colossians as genuinely Pauline and $1: 15-20$ as a traditional Christian hymn, then again Johannine Christology is seen to have earlier precedent. In any case, the Christology of Colossians is not a million miles away from what we find in the undisputed letters of Paul. Even in 1 Corinthians, as we saw, ideas of divine wisdom are in the air, and in 8:6 Paul can comment on the one God and father and the 'one Lord, Jesus Christ, through whom all things are and through whom we live.'

Other significant Pauline texts include Galatians 4:4: 'When the time had fully come, God sent his son, born of a woman.' The 'sending' language and the 'son' language are both rather 'Johannine'. And similar 'son' language is found in Romans 1:3-4, which speaks of 'his son, born of the seed of

\footnotetext{
${ }^{23}$ Ashton finds no Pauline kenosis in the Fourth Gospel (Understanding, 93), but in a passage like 13:1ff. we are not far away from it (also perhaps by implication in 17:24).

${ }^{24}$ There are, of course, plenty of exegetical questions raised by the Philippians hymn, and there are certainly different nuances in the Philippians hymn and Johannine thought. But the similarity is quite sufficient to put a question-mark over any assumption that the fourth evangelist's way of looking at things must be particularly late.
} 
David according to the flesh, set apart as Son of God in power according to the Spirit of holiness by the resurrection of the dead, Jesus Christ our Lord'. The structure of the verses in Romans is reminiscent of the Christ hymn in Philippians 2 ('in the form of God...became man...was highly exalted...Jesus Christ as Lord'), and it may well be that there is a hint of preexistence in the opening 'his son' in Romans 1:3. In any case there is significant 'son' language. Interestingly once again, scholars have seen both Galatians 4:4 and Romans 1:3-4 as early Christian credal material. 25

Such evidence from Paul's letters, then, shows that Johannine Christology has precedent in early Christian tradition, and it makes good sense to propose that much of this early tradition was seen as dominical. This proposal is supported not just by the claims of the Fourth Gospel, but also by the evidence of Matthew 11:27/Luke 10:21,22, mentioned above as possibly having been known by Paul, which speaks in a rather Johannine way of the father and the son. ${ }^{26}$ That Jesus should have been called 'the son' from an early date is not at all unbelievable, given the hardly disputable fact that he addressed God as 'Abba' in a way that impressed people a great deal.27 There is other evidence, too, of Jesus' filial consciousness, including his parable of the rebellious vineyard tenants, where the owner of the vineyard finally sends 'his son'; that parable could well be reflected in a saying such as Galatians $4: 4$, with its description of God sending his son. 28

${ }^{25}$ See, for example, J.D.G. Dunn, Romans 1-8 (Waco: Word, 1988) 5-6; F.F. Bruce, Commentary on Galatians (Grand Rapids: Eerdmans; Exeter: Paternoster, 1982) 194-95.

26It is possible to argue that the Christology of the ' $Q$ ' saying is not identical to the Johannine idea; certainly there is no explicit suggestion of pre-existence. Moreover, it is possible to speculate about an original form of the saying that was 'weaker' in its Christological implications. But the fact remains that highly 'Johannine' Christological language was extant and had been ascribed to Jesus at a rather early date.

27Only this explains Paul's use of the Aramaic word in Rom. 8:15 and Gal. 4:6. On Son of God as Jewish, see Ashton, Understanding, 260-62, citing 4Q246.

28See my Paul, 136-37; also Dunn, Christology, 39-45. 
Finally, on the question of Christology, it is arguable that Paul knew the traditions of Jesus' baptism and transfiguration (in something like the synoptic form). ${ }^{29}$ The evidence for his knowing the baptism includes the similarity of Jesus' baptism as described by the Synoptic Gospels and Christian baptism as understood by Paul (with water, by and with the Spirit, leading to adoption as a 'son' of God). It seems quite likely that for Paul Christian baptism brings the believer 'into Christ', including into Jesus' baptismal experience of anointing by the Spirit (Gal. 3:26-27; 1 Cor. 12:12-13; 2 Cor. 1:2122). 30

If the traditions of the baptism and transfiguration were among those 'received' by Paul, then this further evidence that key 'Johannine' Christological emphases (e.g. Jesus as 'son', 'loved by the father' and closely associated with the Spirit) were familiar and indeed important at an early stage in the history of the Christian church.

We speak of them as important because, if the baptism and transfiguration traditions were well-known, they will inevitably have been seen as highly significant. ${ }^{31}$ For example, the baptism of Jesus will have been seen as a defining moment, being the dramatic moment of Jesus' ecstatic anointing with the powerful charismatic Spirit, the moment when Jesus was revealed as Son of God, and a moment of revelation and knowledge of the father ('Abba'). It is not difficult to see how such an understanding of his baptism might be related to the sort of teaching that is represented in the ' $Q$ ' saying of Matthew 11:25-27/Luke 10:21-22, which speaks about Jesus' own knowledge of the father 32 and about his mediating that knowledge to his disciples. It is also not difficult to see how these strands of thought might then have fed into a view of Christian baptism as a repetition of, or incorporation into, Jesus' Spirit-experience of revelation and sonship (typically being

\footnotetext{
${ }^{29}$ On the transfiguration, see my Paul, 357-63; also Wenham and Moses, 'Some Standing Here'.

${ }^{30}$ See further my Paul, 346-48.

31The supernatural nature of the events will have simply highlighted their importance to many ancient readers/hearers of the traditions.

32Note Luke's opening: 'In that hour he rejoiced in the Holy Spirit'.
} 
associated with charismatic experiences). Arguably such may have been Paul's view and the view of followers of his in a place like Corinth. This will be considered further below.

(iv) 'Love one another'. If even Christology is not a secure indication of the Jamnian context of the Fourth Gospel, 33 what finally of his sectarian-sounding 'Love one another', which seems to contrast with the much more open 'Love your neighbour' and 'Love your enemies' of the synoptic tradition?

Here again Paul sheds important light on the question, since 'love one another' was an important part of his Christian ethic. Thus, for example, in 1 Thessalonians 4:9 he states: 'Concerning love of the brotherhood, you have no need to have anyone write to you. For you are all taught of God to love one another.' In Romans 12:10 he urges his readers to be affectionate 'in brotherly love towards one another', while in Galatians 6:2 he urges the Galatians to bear 'each other's burdens' and so 'to fulfil the law of Christ'.

For Paul, this emphasis on love of fellow-Christians is not something introvertedly sectarian, but is combined with a strong missionary concern and an insistence that Christians should do 'good to all', as well as to the household of faith (Gal. 6:10; $c f .1$ Thess. 5:15). Much the same may be said about the Fourth Gospel. Despite its strong stress on loving fellowbelievers, the Fourth Gospel is fundamentally concerned with God sending his son to bring people to believe (3:16), a commission that is then transferred to the church (20:21).

${ }^{33}$ We do not deny differences between the fourth evangelist and Paul in their Christology, any more than in other ways. But we consider that there is much more in common than has often been appreciated: thus, for example, the stereotype of the fourth evangelist as a more Catholic incarnational thinker and Paul as a more Protestant justificationatonement focusing theologian is at best over-simple, and may reflect a failure to recognise that the Fourth Gospel does not represent the sum of all the evangelist's theology (as is clear from a comparison with 1 John) and that Romans and Galatians do not represent the sum of Paul's thought. That Paul and the fourth evangelist may be closer than has often been thought may be seen in a comparison of the climactic story of Thomas coming to faith in the risen Christ as Lord and God in Jn. 20:24-31 with the important Pauline explanation of salvation in Rom. 10:9. 
Again, Pauline evidence makes it clear that an emphasis of the Fourth Gospel which could point to the Jamnian context could just as well fit into an earlier context. Moreover, Paul's evidence points to 'Johannine' emphases being found in early Jesus-tradition. And this is again the case with the emphasis on 'love one another'.

The most significant evidence in this case is Galatians 6:2, where Paul speaks of carrying each other's burdens and so fulfilling 'the law of Christ'. ${ }^{34}$ This text has been a teasing puzzle to commentators. Why does Paul refer to a 'law' of Christ at all? In Galatians of all letters, he seeks sharply to differentiate the Judaizers' law-based religion and the gospel of Christ; when it comes to speaking of Christian conduct it is a matter of living by the Spirit, not of subjecting oneself to law. And yet, in Galatians 6:2 he urges the Galatians to 'fulfil the law of Christ'. What does Paul have in mind when he uses the phrase? Is it just a slightly odd way of saying that this is the way of Christ? Does he have the teaching of Jesus in general in mind? Or does he specifically have the love command in mind, as attested in the Synoptic Gospels where Jesus affirms loving one's neighbour as a primary command (e.g. Mk. 12:31)?

The last suggestion has merit: Paul speaks of 'the law of Christ' because he has in mind the specific teaching of Jesus about loving one's neighbour. Admittedly the law in question is a law of Moses (Lev. 19:18), not very distinctively the law 'of Christ', but it is possible that it came to be thought of by Christians as Christ's law. Moreover, only a few verses earlier Paul quoted the 'love your neighbour' command as summing up the whole law (5:13-14).

Paul's words in Galatians 5:13-14 are notable for two things. First, they are strikingly similar to the dominical saying of Mark 12:31 and especially to the version of the saying found in Matthew 22:39. Second, they are structurally and verbally similar to Galatians 6:2, as can be seen in the following:

\section{5:13 Through love be slaves to one another.}

For all the law is
6:2 Bear the burdens of one another. And so you will

34See also my Paul, 256-271. 
fulfilled in one word,

fulfil the law of Christ.

'You shall love your

neighbour as yourself'.

Given these striking similarities, the conclusion may seem inevitable that the 'law of Christ' for Paul was indeed 'love your neighbour as yourself', since, as Paul presumably knew, Jesus had strongly endorsed that Old Testament command.

For all the plausibility of this interpretation, there is an alternative explanation that has rarely been considered but which has even greater plausibility, namely that what Paul has in mind when he speaks of the 'law of Christ' is the 'new commandment' of Jesus which is attested in the Johannine tradition. ${ }^{35}$ In John 13:34 Jesus says: 'A new commandment I give to you, that you love one another. As I have loved you that you also love one another. By this shall all know that you are my disciples, if you have love among one another.' The instruction is repeated both in 15:12, where Jesus speaks of 'my commandment', and in 15:17. The command to love one another is referred to also in 1 and 2 John, where it is specifically described as something that you 'heard from the beginning' (1 Jn. 3:11, 23; 2 Jn. 5). This special commandment of the Lord is evidently a well-known tradition in the Johannine community.

Why should it be this tradition that is in Paul's mind in Galatians 6:2? First, because Paul refers (surprisingly, as we saw) to 'the law of Christ' and the fourth evangelist ascribes to Jesus a specific 'commandment', namely the command to 'love one another as I have loved you'. It is true that Paul could have in mind the command to 'love your neighbour' as endorsed by

35R.Y.K. Fung, The Epistle to the Galatians (Grand Rapids: Eerdmans, 1988) 288-89, does make the connection that we suggest, but identifies the Mosaic command to love one's neighbour with the command given by Jesus as a 'new commandment'. A different alternative is offered by $O$. Hofius in his significant article 'Das Gesetz des Mose und das Gesetz Christi', in his Paulusstudien (Tübingen: Mohr, 1989) 50-74 (originally in ZTK 80 [1983] 262-86). He argues that the law of Christ is the way of the cross, and that the phrase 'the law of Christ' is derived from Is. 42:4, the Isaianic Servant passages being so vital in Paul's thinking about the cross. Riesner suggests a possible connection between 1 Thess. 4:9 and Jn. 13:34 (Die Frühzeit des Apostels Paulus, 336). 
Jesus, but, although he probably knew that dominical tradition (and indeed was influenced by it in Gal. 5:14), it is not obvious that Jesus' endorsement of the ancient Mosaic law of Leviticus 5:14 would lead to it being designated 'Christ's law', whereas the Johannine love commandment is quite specifically described as new and as derivative from Jesus. Furthermore, Jesus in the synoptic tradition highlights two Mosaic lawslove God and love your neighbour-so that the singular 'law of Christ' is a little odd, if the reference is to 'love your neighbour'. The Johannine 'love one another' is a singular commandment, ascribed to Jesus, and so fits the case better.

Second, because Paul in Galatians 6:2 explains the law of Christ to entail 'bearing one another's burdens', which corresponds closely to the new commandment of the Fourth Gospel, which is 'to love one another'. In both cases the 'law/commandment' has to do specifically with love for other Christians. We may compare 1 Thessalonians 4:9, where Paul may be echoing the same tradition: 'Concerning love of the brotherhood, you have no need to have anyone write to you, for you are all taught of God to love one another.'

Against this second point, it may be argued that 'love one another' is a perfectly good paraphrastic translation of the Hebrew 'love your neighbour', so that in Galatians 6:2 (and elsewhere) we do not need to postulate any background other than the Mosaic/synoptic 'love your neighbour'. It might similarly be argued that the Fourth Gospel's 'new commandment' is a Johannine version of the Mosaic/synoptic 'love your neighbour'. However, the synoptic evidence suggests that the precise force of 'love your neighbour' was a matter of dispute, and that Jesus himself resisted an interpretation that limited its application to fellow Jews, advocating a broad interpretation (even to the inclusion of enemies; $c f$. Mt. 5:43-47; Lk. 10:25-37). There is no evidence that he interpreted the Mosaic command specifically of love for fellow disciples. It is therefore striking if Paul and the fourth evangelist both give Jesus' endorsement of the 'love your neighbour' command that specific slant, as well as designating this command of Moses as the law/command of Christ (identified in the Fourth Gospel as something 'new'). At least 
we should conclude that Paul and the fourth evangelist have a tradition of interpreting Jesus' words in common. But most probably we should conclude that the 'command/law' of Christ is not 'love your neighbour' (important though that was to Jesus), but a more specific instruction about love among the disciples. 36

The big problem with this proposal may seem to be that, while the synoptists associate the love command with Jesus, it is love of God, of one's neighbour, even of one's enemy, not specifically Christians loving one another. How could they fail to mention what Paul and the fourth evangelist both portray as Jesus' characteristic command? This might seem to point in the opposite direction, suggesting that it was Paul's teaching that gave rise to the Johannine new commandment rather than the other way around.

However, three points are worth making by way of reply to this. First, there is evidence suggesting that so-called Johannine tradition has its roots very early; the $Q$ sayings of Matthew 11:25-27 illustrate this. Second, there is evidence of

36Rom. 13:8, where Paul says 'Owe no one anything, except to love one another' could tell against our argument, since the application in the context is to love in society generally (not to love within the brotherhood). Also in 13:9-10 Paul goes on to speak of love fulfilling the law and of the whole law being summed up in 'Love your neighbour as yourself'. This might appear to support the view the view that Paul derives his teaching about love of the brotherhood from the command to 'love your neighbour', not from the Johannine command. The more likely explanation, however, is that Paul mixes his Jesus-traditions. Thus he can quite appropriately bring together Jesus' teaching about love as the fulfilment of the law with Jesus' teaching about the need for Christians to be loving servants to each other (Gal. 5:13-14; see below for discussion of the servant-teaching); he can use the 'love your neighbour' command to teach Christians about their responsibility to each other (Rom. 15:2; note in 15:3 the appeal to Jesus' example, and compare the Johannine 'as I have loved you'); and occasionally he can use the phrase 'love one another' not just of Christians loving each other (Rom. 13:8). This mixing of traditions is entirely natural, since Paul is not reproducing Jesus' traditions as such, but using them creatively within his own teaching. The evidence in no way undermines our conclusion that Paul knew that there were at least two strands in Jesus' teaching about love, one broader and one narrower: compare 1 Thess. 5:15, or Gal. 6:10. 
Paul being familiar with and influenced by Jesus-traditions. ${ }^{37}$ Third, in this as other cases, it is simplest to explain Paul from the Jesus-tradition than vice versa. Thus, Paul's 'law of Christ' expression is explicable from the Johannine Jesus-tradition, whereas if the fourth evangelist was influenced by Paul we are left without any equally plausible explanation of Paul's language.

As for the synoptists and the new commandment, although they do not directly attest the command to love one another, they come very close to it, particularly in contexts where Jesus discusses relationships between the disciples. This is clear from Mark 9:33-50, where Jesus speaks of receiving other disciples and not causing offence, saying, 'Be at peace with one another'. So too, in Mark 10:41-45, Jesus tells the competitive disciples that they should be servant and slaves to each other, following his example. 38 Matthew similarly emphasises good, forgiving relationships with the brethren, both in the opening antithesis of the Sermon on the Mount (5:21-24) and most notably in chapter 18 .

The Johannine love command is a good example of a feature that is regularly taken to derive from the fourth evangelist and to reflect his context, that context often being

37I argue this in detail in my Paul, where I deliberately did not discuss the Fourth Gospel at any length; but positions taken in this article draw on material found there.

${ }^{38}$ The synoptic thought of 'being servants of each other' following the example of Jesus and of his death has a strong claim to being something quite distinctive of Jesus (much more so than 'love your neighbour as yourself'), and is very close conceptually to the Johannine new commandment, where 'loving one another' is associated with service and the death of Jesus (e.g. Jn. 13). 'Bearing one another's burdens' in Gal. 6:2 is clearly a similar thought ( $c f$. Rom. 15:1-3). Scholars have claimed Paul's familiarity with Mk. 10:45, including in 1 Cor. 9:19, a context where we find some sort of a parallel to the 'law of Christ' of Gal. 6:2, since Paul speaks of himself being 'in Christ's law' (9:21; see my Paul, 266-71). It may also be significant that in Gal. 5:13 we find the idea of love and service combined: 'Through love be servants to one another': for Paul the ideas of loving one another, serving, and of love as fulfilment of the law all come together, and all arguably have a basis in Jesus tradition.

The idea of Jesus' disciples being his family/brothers/sisters also has a basis in tradition (e.g. Mk. 3:35; perhaps Mt. 25:40), for whom there would logically be a special responsibility of 'brotherly' love and loyalty. 
seen as post-Jamnia. If our argument is correct, however, it turns out that Paul knew the 'Johannine' command as a Jesustradition decades before Jamnia. Paul indeed turns out to be an important witness to various Johannine Jesus-traditions.

It is tempting, in view of this conclusion, to take the discussion further, and to ask if there are other Johannine Jesustraditions that Paul may have known. For example, if Paul knew the Johannine 'love one another', did he also know the Johannine story closely connected with that command, namely the washing of the disciples' feet? Although not in the Synoptic Gospels, ${ }^{39}$ the story is historically plausible, being very much akin to Jesus' other acted parables (e.g. his riding into Jerusalem on a donkey and his eucharistic actions) and in keeping with Jesus' well-attested teaching about servanthood (e.g. Mk. 10:45). The depiction of Jesus as the humble servant in Philippians 2 could be derived from the synoptic servant-tradition, but could possibly reflect the Johannine story of Jesus taking the form of a servant and giving his life to 'wash' the disciples. 40

It would be tempting similarly to link Paul's 'in Christ' language with the Johannine emphasis on 'abiding in Christ' and in particular with parable of the vine (Jn. 15), which describes the disciples as branches 'in the vine'. Scholars have offered all sorts of suggestions as to where the Pauline usage comes from: Has it something to do with the corporateness of the idea of the Messiah, or with Genesis 12:3, where Abraham is promised that 'in you all the nations shall be blessed', or with the powerful ritual of baptism, when the immersed convert was plunged 'into' the new reality of Christ? Or is it possible that the Johannine parable of the vine, however much the fourth evangelist may have elaborated it, may have been known to Paul as Jesus-tradition, and that this was a catalyst to his thinking? ${ }^{41}$

${ }^{39}$ Unless Lk. 12:37 and 22:27 hint at Lukan knowledge of the story.

${ }^{40}$ Cf. G.F. Hawthorne, Philippians (Waco: Word, 1983) 78-79; also L. Hurtado, 'Jesus as Lordly Example in Philippians 2.5-11', in P. Richardson and J.C. Hurd (eds.), From Jesus to Paul (Waterloo: Wilfrid Laurier, 1984) 124.

${ }^{41}$ On the history of the Johannine parable of the vine, see R. Bauckham, 'The Parable of the Vine: Rediscovering a Lost Parable of Jesus', NTS 33 
The evidence that we have looked at earlier suggests that these possibilities are not implausible. There may also be something of a cumulative argument emerging, with a whole variety of Johannine materials (not least those found in the farewell discourses) having some sort of Pauline parallels. ${ }^{42}$ But space prohibits the development of these ideas here, and it is not necessary for the argument of this article to do so.

Irrespective of these last two suggestions, the evidence that we have noted earlier not only goes a long way to undermining the Jamnian hypothesis, but also points towards an alternative view-namely that the Johannine traditions of Jesus considered here originate from a time even before Paul, and that they deserve to be treated with as much respect, historically, as do the Synoptic Gospels.

\section{Why is the Fourth Gospel so Different?}

To argue as we have above is only to restate (and hopefully to reinforce with significant new evidence) the kind of view represented by John Robinson, and the weakness of his discussion, as we saw, was that he failed to explain the divergence of the Fourth Gospel from the Synoptic Gospels.

The issue has perhaps begun to be addressed in that we have shown that the Fourth Gospel is not as different from the Synoptic Gospels as has often been supposed. And that argument does not just depend on one or two texts. In fact, there are many more points of convergence than scholars have tended to recognise. It is true, for example, that there are no

(1987) 84-101. S.S. Smalley in 'The Christ-Christian Relationship in Paul and John' (in D.A. Hagner and M.J. Harris [eds.], Pauline Studies [Exeter: Paternoster; Grand Rapids: Eerdmans, 1980] 97-98) finds the whole pattern of divine-human indwelling to be similar in Paul and the fourth evangelist; 'you in God...in Christ...in Spirit; God in you...Christ in you...Spirit in you.' Smalley also finds a similar sacramentalism; the fourth evangelist and Paul both have the idea of conversion as rebirth (Jn. 3; 1 Cor. 4:15; Gal. 4:19). We do not find Paul's 'body' image in the Fourth Gospel, and yet Jn. 2:21 may be significant.

${ }^{42}$ As always, we must beware of parallelomania. Ashton, Understanding, 98, comments that 'Surely any self-respecting Christian syncretist of the period would have shown some Pauline influence'! 
Johannine 'I am' sayings in the Synoptic Gospels, but there are still highly significant 'I am' occurrences (e.g. Mk 6:50; 14:62) and things that come very close to what we have in the Fourth Gospel.43

But that is not to deny the differences. The clue as to the fourth evangelist's intentions is in John 20:31: 'These are written that you may believe that Jesus is the Christ, the Son of God, and that believing you may have life in his name.' This verse sums up almost everything about the Fourth Gospel, and is an overt statement by the author that his purpose is Christological. That statement corresponds to what we find in the Fourth Gospel, with its strong emphasis on the person of Jesus and on the question of who he was. Of course, all the gospels focus on Jesus and are interested in Christology, but, whereas Matthew, Mark and Luke give us a relatively broad picture of Jesus (his ministry and his teaching concerning the kingdom, ethics, the future, etc.), the fourth evangelist homes in much more sharply on the question of the identity of Jesus. Almost every chapter (at least up to chapter 13) is about Jesus as the Messiah, the Son of God and the source of life; the miracles in the Fourth Gospel are signs of Jesus' divinity, not (in the first instance) signs of the kingdom.

The probability must be that this sharp focus reflects the author's situation. He is writing to a situation where there is controversy about who Jesus is. But who particularly does he have in mind?

First, it is probably correct to postulate conflict with 'the Jews', hence the polemical note in the Fourth Gospel and the attention it gives to the question of Jesus' Messiahship. This, however, in no way requires us to think primarily, or

${ }^{43}$ E.g. compare Mt. 7:13-14 on the 'way' to life with Jn. 14:6; Mt. 18:12 on the caring shepherd with Jn. 10; Mt. 11:28-30 with the sentiment of various of the 'I am' sayings. Cf. G. Maier, 'Johannes und Matthäus-Zwiespalt oder Viergestalt des Evangeliums?', in R.T. France and D. Wenham (eds.), Gospel Perspectives II (Sheffield: JSOT, 1981) 267-92.

Occasionally one gets the impression that scholars have tended to read Johannine Christology in as 'high' a way as possible, when in fact the synoptic evangelists are much closer to the fourth evangelist and the later church fathers in their appreciation of Jesus as divine than has sometimes been supposed. 
necessarily at all, in terms of the post-Jamnia situation. There was sharp controversy with the Jews throughout much of the first century, including in the earliest days of the church's life.

Second, there is probably controversy with the followers of John the Baptist in the mind of the author. This is suggested by the considerable attention that is given to the question of Jesus and the Baptist in John 1-4, and by the emphasis that the Baptist was not the Messiah, not the light, and that he came to bear witness to Jesus: 'He must increase, but I must decrease' (3:30). This emphasis very probably is in response to people who were pushing in the opposite direction, making John greater and Jesus less. It is 1:20 that most strongly points in this direction, since the Baptist is there described as follows: 'He confessed, he did not deny but confessed, "I am not the Christ".' It is clear that the evangelist is putting the denial of John in bold type and capital letters, to ensure that his readers get the message loudly and clearly.

There is direct evidence of people who regarded John the Baptist as the Messiah only in the third century A.D. But there is indirect evidence within the New Testament that may point to a Baptist movement continuing after Jesus' death: thus Acts 18:24-19:6 describes people knowing the baptism of John only and needing to be brought into a full understanding of Christian faith (including Apollos and including people in Ephesus, the traditional location of the Fourth Gospel). And there are various oblique hints within the New Testament which may suggest that there were tensions between some followers of John and the early Christians: Matthew 3:13-15 may be Matthew's response to people who claimed that John as Jesus' baptiser was his superior. The silence of the synoptists about many aspects of John's ministry (and of Jesus working for a time in tandem with John as his follower and colleague, as described in the Fourth Gospel) may be a reflection of the same thing. They focus on John's witness to Jesus, and tend to play down his wider significance.

The same is true of the Fourth Gospel, and the author's failure to mention the baptism of Jesus by John may be for the same reason. Whether it is or not, it seems probable that the strong emphasis on the supreme, heavenly status of Jesus in the 
Fourth Gospel is in part a response to a rival Christology in relation to John the Baptist. ${ }^{44}$

A third (possibly related) factor is suggested by the Johannine letters, and in particular 1 John. Scholars are uncertain if 1 John was written by the same author as the Fourth Gospel. But the style and theology of the letter and the Fourth Gospel are at least evidence that they come from the same sort of context and circle. The significant thing from the point of view of this article is that 1 John portrays a split Christian church, the split being over the question of Christology, as depicted in 2:18 and 4:1-3.

The exact nature of the split is uncertain. Some scholars have seen the 'antichrists' as early docetics, whose main fault was in failing to take seriously the 'flesh' of Jesus. But it is not at all certain that they were denying the fleshly humanity of Jesus so soon after his earthly ministry, and perhaps more likely that they were denying that the fleshly Jesus was the Christ, the Son of God. Just conceivably they could have been preferring John the Baptist to Jesus, or more likely separating 'the heavenly Christ' from the man Jesus. The early church tradition which identifies the 'heresy' as a form of Cerinthianism, which claimed that the Spirit descended on Jesus at his baptism and departed before his death, still deserves to be taken seriously. It certainly looks as though the heretics were interested in baptism and the Spirit, but not into the death of Jesus-hence the emphasis in 1 John on the water and the blood, indeed on the water, the Spirit and the blood. It may be that they associated their own baptismal 'anointing' (chrisma) by the Spirit with Jesus' baptismal experience, and saw Jesus as the prototype Christian, on whom the anointing, 'Christ-making', Spirit came and in whom the Spirit dwelt, rather than as one

\footnotetext{
${ }^{44}$ Ashton, Understanding, 167, suspects that the dispute with disciples of John was past history when the gospel was written. Lindars, Gospel of John, 60-61, thinks that it was the Jews, not ongoing 'baptists', who were making John out to be greater than Jesus. I think it is entirely possible that there were continuing followers of John (the view that they all went over to Jesus is over-simple), and that the question of John and Jesus was a much more important ingredient in debate about Jesus in the early church than is often recognised.
} 
who was the incarnate Christ and the eternal Son of God throughout his life, including in his death. 45

It is not difficult to see how such ideas could have been derived from the story of Jesus' baptism, and we suspect that that story spawned a whole variety of 'heretical' ideas, which are responded to in the New Testament. The story gave scope to those arguing for John's superiority (or at least equality) to Jesus, 46 to people advocating an adoptionist Christology, and to the Corinthians with their over-realised eschatology and their special interest in baptism and charismatic experiences. ${ }^{47}$ In

${ }^{45}$ See R.J. Porter, 'That you may know...': An exegetical and historical analysis of the arguments used by the author of 1 John to reassure his readers of the authenticity of their Christian faith and experience' (M.Phil. thesis for Westminster College, Oxford, and the Open University, 1993). 46It might have been argued that the baptism story shows John to have been one who baptised not just with water, but with the Holy Spirit! So was Jesus just a prophet like John, indeed a prophet taking his inspiration from John? The New Testament insistence on associating Spirit-baptism with Jesus could be to counter such a view (including in Acts 19:1-7).

${ }^{47} \mathrm{It}$ is not possible to prove that people like the Corinthians were familiar with the story of Jesus' baptism, but it is possible (1) to show that they knew many Jesus-traditions (see P. Richardson and P. Gooch, 'Logia of Jesus in 1 Corinthians', in D. Wenham (ed.), Gospel Perspectives 5 (Sheffield: JSOT, 1985) 39-62; E.E. Ellis, 'Traditions in 1 Corinthians', NTS 32 (1986) 481-502; and my Paul); (2) to argue for Paul's familiarity with the baptism story (see above); (3) to show the Corinthians' interest in baptism, e.g. 15:29 on the mysterious practice of baptism for the dead.

Various scholars have postulated links between Corinthian enthusiasm and Johannine Christianity (see footnote 20 above), and indeed have connected both with the ' $Q$ ' tradition; we have already noted how Mt. 11:27/Lk. 10:22 has been linked to both 1 Corinthians and the Fourth Gospel. It has been argued that we have a 'gnostic' trajectory in early Christianity, going from $\mathrm{Q}$ to the Fourth Gospel to gnosticism via (among other places) Corinth. See J.M. Robinson and H. Koester's significant work, Trajectories through Early Christianity (Philadelphia: Fortress, 1977). We suspect that there is a grain of truth in this view, but that the true picture is somewhat different. What we have is not a distinctive 'gnostic' Christianity within the early church (comparable to Jewish-Christianity and Pauline Christianity). Rather we see the young church on a broad front wrestling with the traditions that they had received (including the baptism of Jesus) and trying to work out their significance. (On this sort of process in Corinth, see my 'Whatever went wrong in Corinth?', ExpT 108 [1997] 137-41). The traditions concerned and indeed some of the tendencies exhibited in Corinthian and Johannine 
response to such ideas we find all the evangelists in their different ways being careful to put John the Baptist in his place and the synoptic evangelists not even mentioning Jesus' Judean ministry alongside John. We find Paul in Corinthians, the author of 1 John and perhaps the author of Mark's gospel all emphasising the cross to counter a charismatic spirituality that emphasised baptism and the power of the Spirit. ${ }^{48}$ As for the Fourth Gospel, the writer does not suppress the story of Jesus baptising like John, but he has the Baptist speak emphatically about Jesus' superiority and uniqueness. Jesus in the Fourth Gospel is not 'a son' like any other Christian, but is 'the son', with Christians being 'children' of 'my father and your father' $(1: 12 ; 20: 17)$.

If there is anything in these various suggestions and if such tensions were surfacing in the Johannine church when the Fourth Gospel was being written, then the author's energetic engagement with the question of Christology and his sustained affirmation of Jesus as the Christ and the Son of God make sense. He insists that the fleshly Jesus is divine, that he was from the beginning, and that in him (and nowhere else) is life.

Christianity could (and indeed would) lead some in gnostic directions. But in the early period it was less gnosticism and more the sacramental and charismatic nature of early Christianity that is the key to what was going on. And the sacramental and charismatic features of early Christianity are to be traced back not to Greek gnosis (at least primarily) but rather back to the Palestinian roots of Christianity, to Jesus and the early church. There is no need to doubt that Acts is right to portray the earliest Christian church as a baptist, charismatic community, or that the gospels are right to associate Jesus with baptism and charismatic power, and further back still to John the Baptist and indeed to the Essenes (with their emphasis on lustrations, the Spirit and revealed mysteries).

48In Mark the only baptism mentioned after the start of Jesus' ministry is a baptism of suffering (10:38-39). It is one of the puzzles about the Synoptic Gospels that Jesus starts his ministry in a 'baptist' context, but then water baptism does not feature in the ministry of Jesus until we reach the resurrection and the age of the church (so Matthew and Luke). Was baptism not a feature of Jesus' ministry (despite the testimony of the Fourth Gospel to a baptising ministry in Judea), but only of John the Baptist and the church? Or have the synoptics deliberately played down the links between John and Jesus, because they were controversial? On this see Sefa-Dapaah, Investigation. 
There is an interesting parallel in Paul's epistle to the Colossians, where Paul (or the Pauline author) is countering those who 'would make a prey of you by philosophy and human deceit according to human tradition, according to the elemental spirits of the universe, and not according to Christ' $(2: 8-12)$. The nature of the heresy is disputed, but it seems that the heretics, as the author regards them, were putting Christ down. In response, the author emphasises the supremacy of Christ, speaking of Christ as the image of the invisible God, the first-born of all creation, as the one in whom all things were created, in whom the whole fullness of deity dwelt, and in whom there is fullness (i.e. of life). The language is strongly reminiscent of the Fourth Gospel (especially the prologue) and, moreover, both texts portray the cross as a victory (over the prince of this world in the Fourth Gospel, over the principalities and powers in Colossians). There is no need to argue for any close connection between Colossians and the Fourth Gospel or between the heresies countered in the two books (though Colosse is near Ephesus, the city traditionally associated with the writing of the Fourth Gospel); but both suggest a situation where some people are offering a relatively low Christology, and where the canonical authors respond by affirming the supremacy and the pre-existence of Christ, his adequacy for salvation, and his victory.

It seems, then, that the fourth evangelist wrote his gospel in a situation of Christological controversy, a controversy that did not just involve Christians and Jews, but also Christians and those much closer to them-followers of John the Baptist, and even people who were or who had been part of the Christian community. Such a situation explains the evangelist's almost obsessive interest in the question of Christology and his sustained attempt to exalt Jesus. It helps explain the strongly realised eschatology of the Fourth Gospel: the author wants to make it clear that life is to be found in Jesus, now, and that there is no other way (as some of his contemporaries were suggesting). It helps to explain his interest in the Spirit: if the heretics were people who made much of the Spirit and of their experience of the Spirit, then it became important to define the work of the Spirit and to insist that the 
Spirit is closely associated with Jesus (witnessing to Jesus, teaching about Jesus, continuing the work of Jesus). ${ }^{49}$ It also helps explain the strong emphasis on 'loving one another': if the Fourth Gospel was written after a split had taken place in the church, 50 then it is understandable that the author of the Fourth Gospel has a big interest in Christian unity and love (Jn. 17). Abiding in Jesus and in the vine which is the church is especially important, at a time when some have gone out, not 'abiding' with us (cf. Jn. 15; 1 Jn. 2:19).

\section{Conclusion}

This article has raised significant questions about the Jamnian consensus and has offered the beginnings of an alternative, and we think preferable, explanation of the Fourth Gospel's distinctives. We have argued (1) that the distinctives arise out of a very early Christian tradition, not a late mutation in the evolution of Christian doctrine; and (2) that the Fourth Gospel's special emphases are better explained in terms of the sort of Christological debates that we have described than more narrowly in terms of a church-synagogue split at the end of the first century. 51 This has important implications for a consideration of the historicity of the Fourth Gospel, and means that its claim to be based on the eyewitness testimony of 'the beloved disciple' deserves more respect than it is sometimes given. That is not to say that the Fourth Gospel is a verbatim account of Jesus' words and actions, and that the Johannine evangelist has simply selected different material than the

${ }^{49} \mathrm{So}$ too in $1 \mathrm{John}$, where going back 'to the beginning' (the beginning of the Christian story in Jesus) is emphasised (1:1ff)

${ }^{50}$ Many scholars would argue that the gospel was written before the epistles, but, even if they are right, it is quite likely that the split described in 1 John may have been anticipated, manifesting itself already.

51W. Sanday, The Criticism of the Fourth Gospel (Oxford: Clarendon, 1905) 216-235, argues, rightly in our view, that the Christological similarities between Paul, the Fourth Gospel and synoptic sayings such as Mt. 11:27, are to be explained via 'a connection in the main underground' of early Christianity (not through Pauline influence on the fourth evangelist). 
synoptic evangelists: 52 it is hard to deny that the fourth evangelist has often put the traditions into his own words and presented them artistically and creatively. The extent of his creativity is difficult to assess, but it is less significant than many have supposed, and may be more in presentation and less in substance than is often thought.

52But that may well be one further factor explaining his differences. He may be clarifying what the previous gospel traditions had left obscure, whether on Jesus and baptism, or on other matters. The story of Lazarus, for example, may have been deliberately ignored by the synoptists, perhaps for the sake of Lazarus, but the fourth evangelist feels able to use the story, and to make his points through it. 